\title{
Using the Results of Ethnolinguistic Studies \\ in Teaching the Russian Language as a Foreign Language \\ (by the Material of Education Lexis in Russian and Tajik Languages)
}

\section{[Использование результатов этнолингвистических исследований в преподавании русского языка как иностранного (на материале лексики воспитания в русском и таджикском языках)]}

\author{
Tatyana Leontyeva - Evgeniy Dorozhkin - Anna Shchetinina - Khayrullo \\ Tabarov
}

DOI: 10.18355/XL.2016.09.04.100-107

\begin{abstract}
Аннотация
Статья посвящена вопросам использования результатов лингвистических исследований русского лексического материала в практике преподавания русского языка как иностранного или неродного при подготовке учителей русского языка для национальных школ. Утверждается, что накопленная и сохраненная в языковых единицах этнокультурная информация может стать предметом сопоставительного изучения при освоении неродного языка. Оценивается дидактический потенциал лингвистических методов, заключающихся в семантическом и мотивационном анализе слов или фразеологических сочетаний из разных языков, один из которых родной, другой - осваиваемый. В контексте поиска материала для обучения таджикских студентов, которые в будущем планируют стать учителями, методике преподавания русского языка как неродного проводится сравнение лексики тематической группы «Воспитание» в таджикском и русском языках.

Ключевые слова: обучение русскому языку как неродному; лексика; семантика; метафора; русский язык; таджикский язык
\end{abstract}

\section{Введение}

Геополитические процессы на постсоветском пространстве обусловили изменение системы преподавания русского языка как неродного в бывших советских республиках, ставших суверенными государствами. В период существования Союза Советских Социалистических Республик (СССР) в национальных школах велось обучение русскому языку как государственному, что обеспечивало выпускникам школы свободное владение языком. После распада Советского Союза и образования Содружества Независимых Государств появилась необходимость в модернизации национальных систем образования. При этом русский язык перестал быть государственным для стран ближнего зарубежья, но остался языком межкультурной коммуникации.

Как показывают современные исследования, в настоящее время наблюдается тенденция укрепления позиций русского языка в странах ближнего зарубежья, в частности в кавказском и центрально-азиатском регионах. В Таджикистане, как отмечает Р. Д. Салимов, в последние годы значение русского языка в образовательной системе существенно усилилось, что является следствием государственной политики. Исследователь подчеркивает: «Проблема развития таджикского языка как государственного и русского языка как языка межнационального общения является одним из приоритетных 
направлений политики Правительства Республики Таджикистан, что закреплено Конституцией страны и Законом о государственном языке» [Salimov, 2012: 56].

Казахские исследователи Ш. К. Жаркынбекова и А. Ш. Акжигитова говорят о «плодотворно действующей политике Президента Республики Казахстан, направленной на использование трех языков - казахского, русского и английского...» [Zharkynbekova \& Akzhigitova, 2012: 56]. В том и другом случае важность русского языка обусловлена полиэтничностью общества Таджикистана и Казахстана, историческими и культурными связями обоих государств с Россией, а также экономическими связями, которые в настоящее время становятся более крепкими, нежели в предшествовавшие годы - после распада СССР.

Рассматривая роль русского языка в странах Прикаспийского региона, C. С. Оганесян говорит о позитивных моментах, среди которых называет, вопервых, свободное владение политической, административной, интеллектуальной и бизнес-элиты русским языком; во-вторых, прочные традиции обучения русскому языку граждан в данных странах; в-третьих, условия труда в данном регионе, среди которых высокая миграционная активность - отъезд в Россию с целью получения работы, а также обучение специалистов нефтегазодобывающего комплекса и военной сферы в российских вузах [Oganesyan, 2014].

Таким образом, усиление роли русского языка на территории государств ближнего зарубежья, в том числе стран кавказского и центральноазиатского регионов, обусловливает необходимость выработки новых подходов не только к преподаванию русского языка как неродного в школе и вузе, но и к подготовке филологов-русистов, для которых русский язык не является родным. Исследователь из Таджикистана Т. В. Гусейнова указывает на то, что в настоящее время «имеются проблемы с кадровым обеспечением: не хватает около тысячи учителей русского языка, а те, которые работают в системе образования, далеко не всегда владеют нормативной русской речью. В этих условиях, естественно, в речи выпускников школ и студентов учебных заведений с таджикским языком обучения будут грубые речевые ошибки, вызванные интерференцией родного языка» [Guseynova, 2015: 61].

Необходимость новых подходов к подготовке учителей русского языка для национальных школ подтверждают лингводидактические, социолингвистические, этнолингвистические, психолингвистические исследования конца XX - начала XXI вв., которые предлагают не только новые взгляды на развитие разного рода профессиональных компетенций у будущих специалистов-словесников, но и оригинальный лингвистический материал, который может быть использован в процессе подготовки специалиста. Для современной лингводидактики характерен интерес к кумулятивной функции языка. Накопленная и сохраненная в языковых единицах этнокультурная информация может стать предметом сопоставительного изучения при освоении неродного языка. Сравнение результатов семантического и мотивационного исследования тематически близкой лексики разных языков приобретает особое значение в аспекте формирования социокультурной компетенции будущего преподавателя русского языка за рубежом. Эта компетенция предполагает осознание своеобразия представлений о мире, запечатленных во внутренней форме слов, с одной стороны, родного языка, с другой стороны - русского языка как неродного. Ознакомление с особенностями чужой культуры, с иным менталитетом, в том числе через призму ономасиологического подхода к анализу лексики двух языков, позволяет избежать культурного шока.

Данная статья посвящена осмыслению дидактического потенциала лингвистических методов, заключающихся в семантическом и мотивационном 
анализе слов или фразеологических сочетаний из разных языков, один из которых родной, другой - осваиваемый. В контексте поиска материала для обучения таджикских студентов, которые в будущем планируют стать учителями, методике преподавания русского языка как неродного проводится сравнение лексики тематической группы «Воспитание» в таджикском и русском языках. Выбор данной лексико-семантической области в качестве объекта исследования, с одной стороны, обусловлен актуальностью этой тематики в образовательном процессе (педагогические умения и навыки подкрепляются знаниями о том, каким представляется этот процесс - воспитание, обучение носителям разных языков, с какими образами он ассоциируется), с другой стороны, предопределен собственными свойствами слов данной группы: эти слова и выражения часто имеют яркую внутреннюю форму, интересную этимологию, которая проливает свет на представления о том, что значит воспитывать, обучать.

\section{2. Семантика русских и таджикских слов группы «Воспитание»}

Обучая русскому языку студентов-инофонов, нужно знакомить их с лингвистическими методами анализа, в частности с принципами семантического и мотивационного анализа лексики, которые составляют основу этнолингвистических исследований. Следует также пояснить, что лексические единицы русского литературного языка и русских народных говоров имеют много общего, составляют единое пространство. В частности, слова лексикосемантического поля «Воспитание» представлены как в литературной разновидности русского языка (воспитание, формирование, воспитательное воздействие и др.), так и в русских народных говорах (ср. бытующее в Омской области слово стричь 'строго воспитывать, бранить' (Стригут их там, а он все болван) (СРГС, 4: 462)).

В качестве материала анализа особенно интересны глаголы и фразеологические единицы со значением 'воспитывать; воспитание'. Как правило, субъектом помощи выступает взрослый, старший; объектом - тот, кто младше. Характерная черта рассматриваемых номинаций - преимущественная репрезентация представлений об институте семьи: родители воспитывают детей или старшие родственники - младших.

Начать знакомство можно с припоминания и перечисления синонимов слова воспитание или других слов данного лексико-семантического поля: рус. воспитание, обучение, формирование, развитие, образование, воспитательное воздействие; тадж. тарбия / тарбият (заимств. из араб.) 'воспитание', омуззиш 'учение, обучение', маълумот 'образование', сохибмаълумот 'образованный; изучение'. Ср. также рус. воспитанность, благовоспитанность, умение себя вести, учтивость, образованность и тадж. адаб 'вежливость, учтивость, воспитанность, образованность', одоб 'вежливость, почтительность, воспитанность; этика общения' и др.

С точки зрения семантики слов важно представить студентам имеющиеся в двух сравниваемых языках выражения со словом воспитание или родственными ему лексемами: рус. воспитательная работа - тадж. кори тарбиявй, рус. домашнее воспитание - тадж. тарбияи хонагй, рус. школьное воспитание - тадж. тарбияи мактабй, рус. политическое воспитание - тадж. тарбияи сиёси, рус. физическое воспитание - тадж. тарбияи чиисмонй, рус. военно-патриотическое воспитание - тадж. тарбияи хฺарбй-ватандустй, рус. семейное воспитание - тадж. тарбияи оилавй-мактабй, рус. духовное воспитание - тадж. тарбияи маънавй, рус. музыкальное воспитание - тадж. тарбияи мусиқ̧, рус. трудовое воспитание- тадж. тарбияи мехнатй, рус.

102

XLinguae Journal, Volume 9 Issue 4, October 2016, ISSN 1337-8384 
половое воспитание - тадж. тарбияи чунсй, рус. идейное воспитание - тадж. тарбияи воявй, рус. воспитание воли - тадж. тарбияи ирода и др.

На данном этапе занятия формой ознакомления с материалом может быть свободная беседа, поскольку студенты-инофоны, знающие русский язык на базовом или продвинутом уровне, могут принимать участие в соотнесении слов и выражений своего родного языка с русскими номинациями, называемыми преподавателем.

\section{3. Мотивация русских и таджикских слов группы «Воспитание»}

В лексемах со значением 'воспитывать', если смотреть на них с точки зрения мотивации, чаще всего реализуется мотив помощи, поддержки, содействия человеку в развитии и росте, при этом образная основа может быть разной. Демонстрируя студентам-инофонам результаты анализа внутренней формы русских слов, можно перечислить наиболее продуктивные модели номинации. При этом имеет смысл приводить параллели из их родного языка.

Одной из первых нужно представить метафору кормления, которая является едва ли что не универсальной, функционирующей в лексике воспитания в разных языках. Так, в русских номинациях выявляются мотивы «питать», «кормить», «поить». Само слово воспитание апеллирует своей внутренней формой к пища, nuтать. Ср. печор. фольк. воскорми́ть 'вырастить, воспитать' (СРГНП, 1: 90), карел. пита́mь 'воспитывать, растить кого-н.' (Она хотела парня решить [сделать аборт], но она его не решила, а питала) (СРГК, 4: 521), смол. вы́питать 'воспитать' (СРНГ, 5: 328), пск., ряз., онеж. воспойть 'вспоить; вырастить, воспитать' (СРНГ, 5: 142) и др.

Лексика воспитания апеллирует к представлениям о биологическом росте человека: литер. растить; курск. возраста́mь 'воспитывать' (СРНГ, 5: 29), пск., твер., том. взро́стить 'вырастить, воспитать' (СРНГ, 4: 268), пск. израсти́mь 'вырастить, воспитать кого-либо' (СРНГ, 12: 167), олон., ленингр. роще́нье 'воспитание (ребенка)' (Родители невесты берут с жениха плату за рощенье) (СРНГ, 35: 211) и др. Этот же смысл 'делать больше, растить, взращивать' воплощен в тадж. калон кардан, ба воя расондан, ба камол расондан.

Образ качаемого на руках ребенка запечатлен в печор. въ́ккачать 'вырастить' (СРГНП, 1: 106), перм. вы́ммотать (экспр.) 'вырастить' (Вымотала их всех, слава богу, семь человек было) (СПГ, 1: 141), карел. на рука́х переноси́ть 'вырастить (детей)' (На руках одиннадиать [детей] переносила) (СРГК, 4: 458).

Производящие основы поднимать, вздымать, становить, благодаря которым воссоздается образ ребенка, который учится стоять и ходить, выявляются для литер. разг. поднимать и поднимать на ноги 'растить, воспитывать, помогать приобрести самостоятельность' (ССРЛЯ, 10: 480), киров. выздыммámь 'воспитывать, поднимать (детей)' (СРНГ, 5: 282), мурман. постановля́ть 'воспитать, привить определенные навыки' (Робята не постановлень) (СРНГ, 30: 214). Ср. отсылку к слову ноги: арх. до больши́х ног довести́ 'вырастить, воспитать до взрослого состояния' (СГРС, 3: 230). Посредством такого образа передается идея содействия закреплению человека в социальном пространстве. Заметим, что мотивировка «укреплять, придавать стоячее положение, устойчивость» соотносится с мотивом вставания и приобретения устойчивости в русской лексике взросления: литер. самостоятельный, твёрдо стоять на ногах 'быть взрослым, материально самостоятельным', волог. подыма́ться 'воспитываться' (Она-то у бабушки всё подымалася) (СРНГ, 28: 272), пск. на ногу вздёрнуться 'повзрослеть' (СПП: 57), волог. выстава́mь 'воспитываться, вырастать' (Я не встану, не выстану без кормильйа, без батюшки) (СРНГ, 6: 29). Для сравнения приведем тадж. ба воя 
расонидан 'растить, воспитывать, взращивать, доводить до состояния зрелости' (букв. «поднимать»), ба по мондан, бо хуни дил калон кардан, хуни дил хуррдан, чзонро дар ченаш мондан, умрро дар тарбияаш сарф кардан, қоматашро рост кардан, ба баловат расондан.

Представление о том, что воспитывать значит ухаживать, заботиться, любить, передается посредством привлечения глаголов позитивного эмоционального состояния и отношения нежить, лелеять, кохать 'любить': тобол. выне́жсивать 'заботливо воспитывать в неге, холе' (СРНГ, 5: 317), вят. отлеле́ять 'заботливо воспитать, вырастить кого-либо; взлелеять' (СРНГ, 24: 224), брян., курск., волгоград. коха́ть 'воспитывать' (СРНГ, 15: 120). Преимущественно это диалектные слова, то есть модель непродуктивна в русском литературном языке.

Обнаруживается также метафора вскармливания животными детенышей, птицами - птенцов: перм. выпа́ривать 'высиживать (о куриценаседке)' и 'выращивать (о детях)' (Я всего одну дочку выпаривал. А как выпарил, уехала она от меня, взрослая стала) (СПГ, 1: 143), волог. вйносить в зуба́x 'вырастить без чьей-либо помощи' (А пусть дитё! Я в зубах его выношу, без мужа, а воспитаю) (СРГК, 2: 258). Этому значению в таджикском языке соответствует выражение як лахти гуиштро одам кардан.

В лексике воспитания очень активны мотивы движения.

Привлечение глаголов вести, тянуть в качестве источников семантической деривации свидетельствует о том, что воспитание концептуализируется в русском языке как совершение совместных перемещений субъекта и объекта воздействия в некотором жизненном пространстве: ряз. води́ть 'воспитывать, растить' (Девочек этих жалей, води их) (Деул. сл.: 90), перм. вести́ 'держать в каком-либо состоянии, воспитывая, наблюдая' (Раньше-то нас строго вели, подбирали, в шесть вечера домой загоняли) (СПГ, 1: 90), перм. вб́іводить 'вырастить, воспитать, вынянчить' (Я $и$ двойников выводила) (СПГ, 1: 132). Один из них занимает активную позицию ведущего, а другой - позицию ведомого.

Мотивировочный признак «подсказать направление» выявляется в литер. наставлять, ставить на путь истинный, давать наставления, пск. напра́вить 'указать правильное направление в жизни, наставить' (ПОС, 20: 162), брян., смол. припутúmь 'приучить к делу, воспитать, вывести в люди' (СРНГ, 31: 361).

Мотив сопровождения в сочетании с мотивом трудности, приложения усилий эксплицируются в арх. вытяга́mь 'с трудом растить' (СРНГ, 6: 46), перм. волока́ть 'растить, воспитывать' (Робят вместе волокали) (СПГ, 1: 114). Оценка воспитания как трудного, требующего приложения многих усилий процесса присутствует и в тадж. дар тарбияи у чцонканй кардан, газида калон кардан, як лахти гуиштро калон кардан, бо хуни дил калон кардан 'воспитывать, прилагая отчаянные усилия, с трудом растить, выносить мучения, страдания'.

Воспитывать ребенка значит подводить, тянуть его к некоторой черте, за которой, согласно буквальному прочтению ряда фразеологизмов, находится место дислокации дела и ума - маркеров возраста и социальной зрелости: новосиб. довести́ кого до кра́ю 'вырастить, воспитать кого-л., ставшего совершеннолетним, самостоятельным' (ФСРГС: 61), омск. к де́лу привести́ 'довести до дела, вывести в люди, научить, воспитать' (СРНГ, 31: 142), новосиб. довести́ до де́ла (ума́) 'вырастить, воспитать ребенка, научив его какому-либо делу' и 'вырастив, воспитав, выдать замуж дочь (сына - женить)' (ФСРГС: 61).

Воспитание детей концептуализируется как их «взращивание» до момента «погружения» в «людскую» среду, то есть в социум: ленингр. в лю́ди cnycmúmь 'вырастить, вывести в люди' (Я такая семистая, семеро рожено, 
в люди спустила) (СРГК, 3: 169), волог. лю́довать 'вырастить, вывести в люди' (Шутка, людовать семеро детей) (СРГК, 3: 169). Таджикскими эквивалентами являются выражения ба воя расондан, ба баловат расондан, ба камол расондан.

Запечатленные лексическими средствами представления о воспитании, таким образом, концентрируются вокруг образа воспитуемого (младенца, ребенка, не умеющего стоять, несамостоятельного в передвижении, требующего ухода, питания) и воспитателя (взрослого, выполняющего определенные функции: он кормит, качает, ведет, ставит, направляет, заботится). Таков «ассортимент» образных элементов в мотивации анализируемых слов русского языка, который в некоторой своей части совпадает с набором образов, характерных для лексики воспитания в таджикском языке.

\section{4. Выводы}

Итак, в процессе изучения русского языка инофонами-русистами актуален сравнительный анализ национально-маркированной лексики изучаемого и родного языков. Привлечение такого материала позволяет обратить внимание студентов на разность менталитетов, на межкультурные различия, зафиксированные лексическими средствами каждого из языков, и одновременно показать, что воспитание осмысливается представителями разных культур во многом сходным образом. Именно этот второй аспект обнаружение сходств - дает почву для взаимопонимания и сближения участников коммуникации, для адаптации в новой культурно-языковой среде.

Если обобщить содержание приведенных выше дефиниций и контекстную сочетаемость русских слов семантической группы «Воспитание», то можно утверждать, что семантический акцент делается преимущественно на цели воспитания, на его результате:

- $\quad$ воспитать до брака, создания семьи;

- $\quad$ воспитать до обзаведения своим хозяйством;

- $\quad$ воспитать до трудоспособности;

- $\quad$ воспитать до жизни в миру, в социуме.

Анализ мотивации русских слов позволяет провести экспликацию мотивов, весьма разнообразных, но характеризующих преимущественно приемы воспитания, то есть образ действия «воспитателя» (он, как старший или как родитель, «кормит», «растит», «нежит», «качает на руках», «ведет», «тянет», «указывает направление»), и лишь во вторую очередь актуализирующих цель воспитания («приобретение устойчивости», «включение в социум»).

Часть этих мотивов («кормить», «растить», «придавать устойчивость, поднимать на ноги») реализуется и в лексике таджикского языка (хуррондану пушиондан, калон кардан, ба пой мондан, ба камол расондан и др.) - родного для студентов, которым предлагается данная методическая разработка.

При подготовке занятия, разрабатываемого с применением результатов этнолингвистических исследований, можно использовать также номинации других лексико-семантических групп. С целью поиска и отбора обучающего материала необходимо осуществить поиск подобных исследований, выполненных русскими и таджикскими учеными, соотнести результаты таких работ, сформировать наиболее репрезентативные подборки лексики. Студентаминофонам, будущим учителям, может быть предложено провести собственные изыскания на примере какой-либо тематической группы лексики, чтобы освоить этнолингвистический инструментарий.

\section{Bibliographic references}

GUSEYNOVA, T. V. 2015. O sociolingvisticheskih i didakticheskih problemah prepodavaniya russkogo yazyka $\mathrm{v}$ Respublike Tadzhikistan. In: Sociokulturnoe 105 
prostranstvo Rossii i zarubezhya: obshhestvo, obrazovanie, yazyk, n. 4, pp. 59-67. ISSN 2312-3281

OGANESJaN, S. S. 2014. Rol' i znachenie russkogo yazyka dlya stran Prikaspiiskogo regiona. In: Elektronnoe nauchnoe izdanie al'manah Prostranstvo i vremya, vol. 5, n. 1-2, p. 11. ISSN 2227-9490.

SALIMOV, R. D. 2012. Problemy yazykovoi politiki i razvitiya yazykov v mnogoyazychnom Tadzhikistane. In: Slovo.ru: Baltiiskii akcent, n. 2, pp. 56-60.ISSN 2225-5346

ZHARKYNBEKOVA, SH. K. - AKZHIGITOVA, A. SH. 2012. Yazykovaya politika kak instrument vozdeistviya i formirovaniya onomasticheskogo prostranstva

g. Astany. In: Vestnik Moskovskogo gosudarstvennogo lingvisticheskogo universiteta, n. 24 (657), pp. 48-57. ISSN 1993-4750

\section{Material resources}

Деул. сл. - Slovar' sovremennogo russkogo narodnogo govora (d. Deulino Ryazanskogo rayona Ryazanskoy oblasti). 1969. Moskva: Nauka.

ПОС - Pskovskii oblastnoi slovar' s istoricheskimi dannymi. 1967-2008. Leningrad: Izd-vo Leningradskogo un-ta, t. 1-20.

СГРС - Slovar' govorov Russkogo Severa. 2001-2009. Ekaterinburg: Izd-vo Ural'skogo un-ta», t. 1-4.

СПГ - Slovar' permskih govorov. 2000-2002. Perm': Knizhnyi mir, n. 1-2.

СПП - Slovar' pskovskih poslovic i pogovorok. 2001. Sankt-Peterburg: Norint.

СРГК - Slovar' russkih govorov Karelii i sopredel'nyh oblastei. 1994-2005. SanktPeterburg: Izd-vo Sankt-Peterburgskogo un-ta, n. 1-6.

СРГНП - Slovar' russkih govorov Nizovoi Pechory. 2003-2005. Sankt-Peterburg: Filologicheskii fakul'tet SPbGU, t. 1-2.

СРГС - Slovar' russkih govorov Sibiri. 1999-2006. Novosibirsk: Nauka. Sib. predpriyatie RAN, t. 1-5.

СРНГ - Slovar' russkih narodnyh govorov. 1965-2011. Moskva; Leningrad; SanktPeterburg: Nauka, vyp. 1-44.

ССРЛЯ - Slovar' sovremennogo russkogo literaturnogo yazyka. 1948-1965. Moskva: Nauka; Leningrad: Izdatel'stvo AN SSR, t. 1-17.

ФСРГС - Frazeologicheskii slovar' russkih govorov Sibiri. 1983. Novosibirsk: Nauka, Sibirskoe otdelenie.

\section{Сокращения}

араб. - арабское

арх. - архангельское

букв. - буквально

брян. - брянское

волгоград. - волгоградское

волог. - вологодское

вят. - вятское ${ }^{1}$

карел. - карельское

киров. - кировское

курск. - курское

$$
\begin{aligned}
& \text { омск. - омское } \\
& \text { онеж. - онежское } \\
& \text { перм. - пермское } \\
& \text { печор. - печорское } 2 \\
& \text { пск. - псковское } \\
& \text { разг. - разговорное } \\
& \text { рус. - русское } \\
& \text { ряз. - рязанское } \\
& \text { смол. - смоленское } \\
& \text { тадж. - таджикское }
\end{aligned}
$$

\footnotetext{
1 Административная единица Российской империи, СССР (ныне на этих территориях располагаются части Кировской области, Удмуртии); Олонецкая губерния - административная единица Российской Империи с центром в г. Петрозаводске.

${ }^{2}$ Печор. - записанное по реке Печоре.
} 
ленингр. - ленинградское

литер. - литературное

мурман. - мурманское

новосиб. - новосибирское

олон. - олонецкое ${ }^{1}$ твер. - тверское

тобол. - тобольское

том. - томское

фольк. - фольклорное

The study is supported by Russian Science Foundation (project No. 16-18-02075 "Russian Society in the Mirror of Lexical Semantics"). | Исследование выполнено за счет гранта Российского научного фонда (проект № 16-18-02075 «Русский социум в зеркале лексической семантики»).

Words: 2966

Characters: 23856 (13, 25 standard pages)

Tatyana V. Leontyeva, Doctor.

Russian State Vocational Pedagogical University

Mashinostroitelej 11

620098 Yekaterinburg

Russia

leotany@mail.ru

Evgeniy M. Dorozhkin, Doctor, Prof.

Russian State Vocational Pedagogical University

Mashinostroitelej 11

620098 Yekaterinburg

Russia

evgeniy.dorozhkin@rsvpu.ru

Anna V. Shchetinina, PhD.

Russian State Vocational Pedagogical University

Mashinostroitelej 11

620098 Yekaterinburg

Russia

anna-73.schetinina@yandex.ru

Khayrullo N. Tabarov, PhD.

Russian-Tajik (Slavic) University

M. Tursun-zade 30

734000 Dushanbe

Tajikistan

tabarov-64@mail.ru 